\title{
CYTOTOXICITY OF IONS RELEASED FROM 17-4 PRECIPITATION HARDENING STAINLESS STEEL ORTHODONTIC BRACKETS IN ARTIFICIAL SALIVA
}

\author{
TJOKRO PRASETYADI ${ }^{1}$, BAMBANG IRAWAN ${ }^{2}$, MIESJE KARMIATI PURWANEGARA ${ }^{3}$, BAMBANG SUHARNO ${ }^{4}$, \\ SUGENG SUPRIADI ${ }^{5 *}$
}

${ }^{1}$ Ph.D. Program, Faculty of Dentisry, Universitas Indonesia, Jakarta, Indonesia. ${ }^{2}$ Department of Dental Materials, Faculty of Dentistry, Universitas Ind onesia, Jakarta, Indonesia. ${ }^{3}$ Department of Orthodontics, Faculty of Dentisry, Universitas Indonesia, Jakarta, Indonesia. ${ }^{4}$ Department of Metallurgy and Material Engineering, Faculty of Engineering, Jawa Barat, Universitas Indonesia, Indonesia. ${ }^{5}$ Department of Mechanical Engineering, Faculty of Engineering, Universitas Indonesia, Jawa Barat, Indonesia. Email: bisosro15@yahoo.co.id

Received: 16 September 2017, Revised and Accepted: 3 October 2017

ABSTRACT

Objective: 17-4 precipitation hardening (PH) stainless steel has a low nickel content, which can reduce the risk of allergic reactions. It also has good mechanical properties against the stress caused by the archwire slot brackets in orthodontic treatments. The main focus of this study to evaluate the metal ions released into artificial saliva from different orthodontic brackets with the same 17-4 PH stainless steel and to examine the in vitro cytotoxicity of the metal.

Methods: Material properties were analyzed by energy dispersive spectroscopy. The 3-(4,5-dimethylthiazol-2-y1)2,5-diphenyltetrazolium bromide (MTT) assay method was used to examine the cytotoxicity of Gemini and Synergy brackets.

Results: The cytotoxicity test on all the orthodontic brackets showed a mean cell viability value above $80 \%$ in each immersion group, which means that this material is not cytotoxic to the human immortalized keratinocyte cell line.

Conclusions: The results showed cell viability in the extracts of both groups of brackets, and there was no statistically significant difference between the groups $(\mathrm{p}>0.05)$.

Keywords: Cytotoxicity, Corrosion, Nickel, Chrome, Orthodontic brackets.

(C) 2017 The Authors. Published by Innovare Academic Sciences Pvt Ltd. This is an open access article under the CC BY license (http://creativecommons. org/licenses/by/4. 0/) DOI: http://dx.doi.org/10.22159/ijap.2017.v9s2.17

\section{INTRODUCTION}

Based on previous research, stainless steel orthodontic brackets containing nickel and chrome ions can trigger allergic reactions in some patients. The material selected must be corrosion-resistant so that the chemical reaction between the ions and the oral environment is safe for humans. The oral environment (i.e., bacteria, saliva, and diet) of every individual has an influence on the occurrence of corrosion, in addition to pressure or friction from archwires [1]. Some compounds containing metals such as nickel $(\mathrm{Ni})$, chromium $(\mathrm{Cr})$, and cobalt (Co) can cause allergic reactions or can be toxic or mutagenic. These metal ions can be released due to several factors such as temperature, $\mathrm{pH}$, mechanical stress, and corrosion due to the microflora. The cytotoxicity of orthodontic brackets can be determined by measuring the number of ions released as a consequence of corrosion either in vitro or in vivo [2]

The World Health Organization recommends a daily dose of 50-200 mg/ day for chromium and $25-35 \mathrm{mg} /$ day for nickel. Cytotoxicity can be studied in vitro, with the advantage of being able to control the variables that affect the release of metal ions; in vivo studies involve many potential confounding variables such as saliva composition, $\mathrm{pH}$, diet, and microflora, making it difficult to analyze the resulting data. Nevertheless, in vivo studies better capture the actual conditions. The highest concentration of metal ions is released in the early stages of the experiment, creating what is called a passive layer, and then, the number of ions released gets lower [2].

From 2015 to 2016, there was a research collaboration between the faculty of dentistry and the faculty of engineering department of metallurgical and materials, University of Indonesia. This study analyzed heat-treated $17-4$ precipitation hardening $(\mathrm{PH})$ stainless steel in the oral cavity environment, examining such variables as artificial saliva, $\mathrm{pH}$, microflora, and reactions toxic to the cell. 17-4 PH stainless steel has a low nickel content, which can reduce the risk of allergies, and this material has good mechanical properties against stress caused by the archwire to the slot of brackets in orthodontic treatments [3-5]. This study aimed to evaluate the metal ions released into artificial saliva from different orthodontic brackets with the same 17-4 PH stainless steel and to examine their in vitro cytotoxicity.

\section{METHODS}

\section{Sample preparation}

The two types of orthodontic brackets that were evaluated were 0.022 slot 17-4 PH stainless steel (Gemini $\left.{ }^{\circledR}, 3 \mathrm{M}, \mathrm{USA}\right)$ and 0.022 slot $17-4 \mathrm{PH}$ stainless steel (Synergy ${ }^{\circledR}, \mathrm{RMO}, \mathrm{USA}$ ). The elements of the material were analyzed by energy dispersive spectroscopy (EDS; EVO MA-10 model, Zeiss, Germany). Both groups of bracket orthodontics were measured, weighed, autoclaved, and immersed in artificial saliva with pH 7 in sterile borosilicate glass containers. The artificial saliva had the following composition: $\mathrm{NaCl} 0.7 \mathrm{~g} / \mathrm{L}, \mathrm{KSCN} 0.33 \mathrm{~g} / \mathrm{L}, \mathrm{NaHCO}_{3} 1.5 \mathrm{~g} / \mathrm{L}$, $\mathrm{KCl} 1.2 \mathrm{~g} / \mathrm{L}$, urea $0.13 \mathrm{~g} / \mathrm{L}, \mathrm{Na}_{2} \mathrm{HPO}_{4} 0.26 \mathrm{~g} / \mathrm{L}$, and $\mathrm{KH}_{2} \mathrm{PO}_{4} 0.2 \mathrm{~g} / \mathrm{L}$

The amount of saliva used was calculated with a ratio of $10 \mathrm{ml}$ of artificial saliva to $0.01 \mathrm{~g}$ of brackets. Both groups were immersed and incubated at $37^{\circ} \mathrm{C}$ for 16,28 , and 35 days. After the immersion period was complete, all the brackets were removed from the glass containers, and the artificial saliva with corrosive products was stored at $4^{\circ} \mathrm{C}$ until analysis. Scanning electron microscopy (EVO MA-10 model, Zeiss, 
Germany) was used to analyze the surface of the brackets before and after exposure to artificial saliva.

The separated metal ions were measured by inductively coupled plasma mass spectrometry (ICP-MS) with a minimum reading of $0.005 \mathrm{mg} / \mathrm{L}$.

\section{Cell culture}

Human immortalized keratinocyte cell line (HaCaT) cell cultures were produced by treatment with (Dulbecco's Modified Eagle Medium, Gibco, CA, USA) supplemented with 10\% (fetal bovine serum; Caisson Laboratories Inc., Logan, UT, USA) $100 \mathrm{IU} / \mathrm{mL}$ penicillin, $100 \mathrm{mg} / \mathrm{mL}$ streptomycin (Caisson Laboratories), and $25 \mathrm{mg} / \mathrm{mL}$ Fungizone (Biobasic Inc., Ontario, Canada) at $37^{\circ} \mathrm{C}$ in a humidified atmosphere containing $5 \% \mathrm{CO}_{2}$. Then, a cell confluent, with trypsinized and suspended cells used for cytotoxicity experiments, was incorporated into the cell culture in a 96-well flat with a concentration of $3.5 \times$ $10^{5}$ cells $/ \mathrm{mL}$ ( $100 \mathrm{~mL}$ total). After $24 \mathrm{~h}$ in a humidified atmosphere containing $5 \% \mathrm{CO}_{2}$, the cell monolayer was ready.

\section{3-(4,5-dimethylthiazol-2-y1)2,5-diphenyltetrazolium bromide (MTT) assays}

The MTT method was used to analyze the cytotoxicity of both groups of brackets. The evaluation of the cytotoxicity of the corrosion products of $17-4 \mathrm{PH}$ stainless steel was performed by adding $20 \mathrm{~mL}$ of each incubated sample $(16,28$, and 35 days) to the 96 -well plate that already contained a monolayer of epithelial cells HaCaT. The samples were incubated for $24 \mathrm{~h}$. Cytotoxicity tests were performed by adding the reagent MTT to a 96-well plate that was preincubated for $24 \mathrm{~h}$ and contained medium, cells, and artificial saliva. Then, $10 \mathrm{~mL}$ of MTT reagent was added to each plate, and they were incubated for $3 \mathrm{~h}$ in a $\mathrm{CO}_{2}$ incubator. MTT reagent activates the mitochondria of living cells so that they can be read by an enzyme-linked immunosorbent assay (ELISA reader). After that, $50 \mathrm{~mL}$ of acidified isopropanol was added to each plate, followed by centrifugation for $1 \mathrm{~h}$ at a $0.75 \mathrm{rpm}$ rotational speed.

Finally, a 96-well ELISA plate was inserted into the reader to analyze the toxicity of the ions removed from the stainless steel extract against epithelial cells, as measured by the viability of the cells. The optical density (OD) was measured at a wavelength of $550 \mathrm{~nm}$ in an ELISA microplate reader. For controls, some cells were incubated with a medium containing artificial saliva without stainless steel extracts to gain $100 \%$ viability or metabolic activity of the cells. The OD was used as a reference to describe the cytotoxicity (\%) in the assay.

\section{Statistical analysis}

The mean difference between the experimental groups was analyzed statistically using unpaired t-tests. $p$ value was significant if $p<0.05$. Data that did not qualify for parametric tests were tested with the nonparametric Mann-Whitney test.

\section{RESULTS}

The results of the EDS showed that both groups of orthodontic brackets were 17-4 PH stainless steel. The $\mathrm{Ni}$ and $\mathrm{Cr}$ extract concentrations in both groups after immersion for 16,28 , and 35 days indicated that the metal ions released were $<5 \mu \mathrm{g} / \mathrm{L}$. A slight weight change occurred on Gemini $^{\circledR}(\mathrm{G})$ at 16 and 28 days of immersion, reducing the weight by $0.16 \mathrm{mg}$ and $0.26 \mathrm{mg}$, respectively, whereas the Synergy ${ }^{\circledR}(\mathrm{S})$ bracket weights did not change. The scanning electron microscopy analysis showed that the surfaces of the brackets had not pit corrosion (Fig. 1).

We used HaCaT cells in saliva without extracted metal ions as controls (99.46\%).The percentage of cell viability of the G samples decreased after immersion of 16 days (93.7\%), whereas the Group G sample immersed for $28(123.7 \%)$ and 35 days (106.4\%) had increased cell viability. Similar results were seen with the $\mathrm{S}$ samples after immersion for 16 days (105.57\%), 28 days (120.30\%), and 35 days (106.85\%) (Table 1).

The cell viability fluctuated in each group of brackets with the same characteristics that occurred in a low percentage of the 16-day
Table 1: Percentage of cell viability in $G$ and $S$ extracts

\begin{tabular}{lllll}
\hline Group & Group & $\mathbf{N}$ & Mean \pm SD & $\mathbf{p}$ \\
\hline $\begin{array}{l}\text { Percentage viability } \\
\text { cell }\end{array}$ & G-16 days & 4 & $93.700 \pm 18.0688$ & 0.288 \\
& & & & \\
& S-16 days & 4 & $105.575 \pm 9.4641$ & \\
& G-28 days & 4 & $123.175 \pm 19.2512$ & 0.782 \\
& S-28 days & 4 & $120.00 \pm 4.9173$ & \\
& G-35 days & 4 & $106.400 \pm 10.5606$ & 0.955 \\
& S-35 days & 4 & $106.850 \pm 11.2281$ & \\
\hline
\end{tabular}

${ }^{*}$ Gemini ${ }^{\circledR}(G)$ and Synergy ${ }^{\circledR}(S)$ orthodontic brackets, ${ }^{*}$ The mean difference between the experimental groups was analyzed statistically using unpaired t-tests. $P$ value was significant if $\mathrm{p}<0.05$. SD: Standard deviation

immersion group, then increased after 28 days and decreased after 35 days. Fig. 1 shows the difference between the two groups of G and $S$ brackets in each group immersion. However, the $G$ and $S$ extracts did not have significant differences in cell viability ( $p>0.05)$.

\section{DISCUSSION}

One of the components of artificial saliva is a combination of chloride and sulfate ions that causes a corrosion reaction with the ability to ruin the formation of film on stainless steel surfaces and decrease the corrosion protection [6]. This phenomenon can also be caused by internal stress in the metal or by any nonhomogeneous microstructures of the metal; for example, a stainless steel bracket that has $\mathrm{Cr}-\mathrm{Fe}-\mathrm{Ni}$ is able to form a passive film containing $\mathrm{Cr}_{2} \mathrm{O}_{3}$. The cytotoxicity of stainless steel depends on the nature of the film layer. 17-4 PH stainless steel material has nickel content in the range of $3-5 \%$ but almost the same corrosion resistance as stainless steel containing $8-12 \%$ nickel. The manufacturing process of the orthodontic brackets also influenced the corrosion resistance of each group [7].

The results of cell viability for the Gemini ${ }^{\circledR}$ were lower in the 16-day immersion, illustrating that a high concentration of metal ions was released at the beginning of the experiment, after the possibility of a passive layer [2]. The SEM showed that there were no differences between the topographies of the brackets before and after treatment. Furthermore, in the 28- and 35-day immersion groups, there was no pit corrosion on the body of either the Gemini ${ }^{\circledR}$ or Synergy ${ }^{\circledR}$ brackets. The MTT assay, although not always accurate, evaluates mitochondrial succinic dehydrogenase activity by calculating the amount of formazan produced by the enzyme. The results showed that the extracts of nickel and chromium from the Gemini ${ }^{\circledR}$ had effects on cell viability, especially in the 16-day immersion group. In this group, the metal ions stimulated cell reactions, thus decreasing the amount of cell function, including succinic dehydrogenase activity and protein synthesis; the higher amount of nickel and chromium in the Gemini ${ }^{\circledR}$ was likely the cause [8]. However, the results of the 28- and 35-day immersion groups showed higher percentages of cell viability than the controls, the cell viability of the Synergy ${ }^{\circledR}$ was also greater than the controls (100.53\%).

It was found that the ions were released in doses that are not cytotoxic to humans. These results indicate that both orthodontic brackets are relatively biocompatible with $\mathrm{HaCaT}$ cells. The results of ion release analysis with ICP-MS test in 16, 28, and 35 days immersion showed that the amount of chromium and nickel ions released were under $0.005 \mathrm{mg} / \mathrm{L}$ for all orthodontic bracket samples. If in 35 days, the ion is released, for example, as much as $0.005 \mathrm{mg}$, then, the estimated concentration of the ion release of nickel or chromium in a day is equal to $0.1 \mu \mathrm{g} / \mathrm{L}$. The released ions are still below the WHO recommended threshold value of 50-200 g/day for chromium and 25-35 g/day for nickel.

This finding is in agreement with several studies that support the cytotoxicity its alloys. Sauza and Menezes, result of this study revealed an increase of nickel and chromium in saliva of individual after $10 \mathrm{~min}$ placement of appliance, after that there is a tendency for stabilization of the amount of metal released, this factor may reduce corrosion 

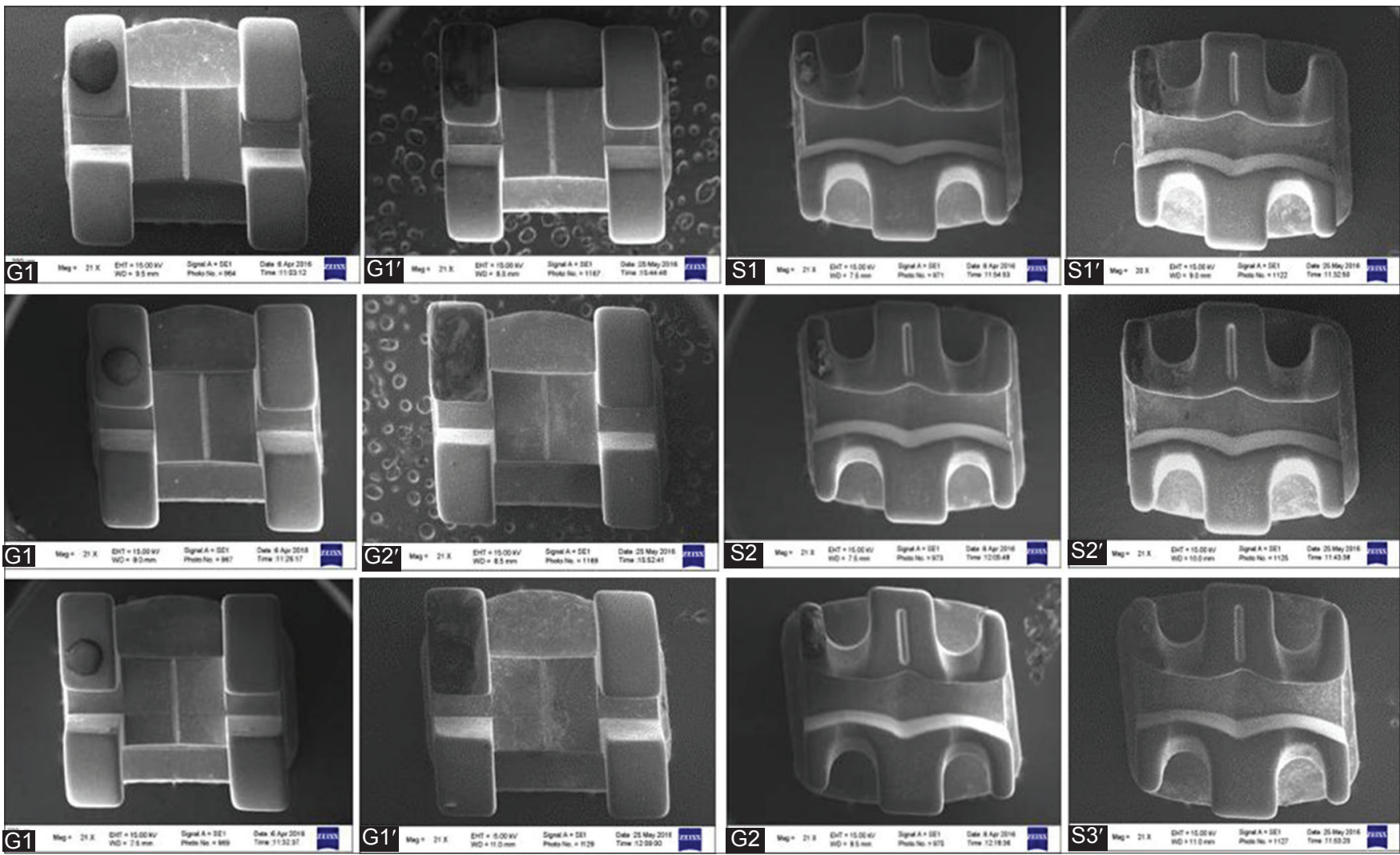

Fig. 1: Scanning Electron Microscopy analysis of Gemini ${ }^{\circledR}(G)$ and Synergy ${ }^{\circledR}(S)$ orthodontic brackets (before and after immersion artificial saliva), (G1) - 16 days, (G2) - 28 days, (G3) - 35 days, (S1) - 16 days, (S2) - 28 days, (S3) - 35 days

in vivo [9]. Mikulewicz et al., the result of this study also showed that the highest concentration of ion released was at the beginning of the experiment. It was found passivation probably occurred from stainless steel and it found that the ion released is not toxic to humans [2].

\section{CONCLUSION}

This study shows that cells have different responses to each 17-4 PH stainless steel orthodontic bracket, although there was no statistically significant difference between the cytotoxicities of the Gemini ${ }^{\circledR}$ and Synergy ${ }^{\circledR}$ brackets. However, the increase in cell viability over the course of the immersion time shows that more research needs to be done to understand the cytotoxicity of long-term treatments.

\section{ACKNOWLEDGMENTS}

The authors acknowledge to Dr. Endang W. Bachtiar, M. Biomed, PhD for supervision in laboratory work at oral biology laboratory, faculty of dentistry, University of Indonesia.

The publication of this manuscript is supported by Universitas Indonesia.

\section{REFERENCES}

1. Vyas R, Issaid MA, Idris BA. Cytotoxicity and corrosive resistance: A review. Cairo Dent J 2009;25:361-5.
2. Mikulewicz M, Chojnacka K, Wolowiec P. Release of metal ions from fixed orthodontic appliance: An in vitro study in continuous flow system. Angle Orthod 2014;84:140-8.

3. Mohammad DW. Influence of Streptococcus mutans and Streptococcus pyogenes bacteria on microbiology-induced corrosion and cytotoxicity of heat-treated stainless steel 17-4 PH.University Indonesia library 2015;S58677:50.

4. Arlan AS. Influence of Streptococcus sobrinus and Candida albicans on microbiology-induced corrosion and cytotoxicity of heattreated stainless steel 17-4 PH. University Indonesia library 2015; S60832:30.

5. Abdullah $\mathrm{H}$. Effect of aging at $570^{\circ} \mathrm{C}$ on mechanical properties and aging at $540^{\circ} \mathrm{C}$ on in vitro biocompatibility of ion hexavalent chromium release of 17-4 PH stainless steel. University Indonesia library 2016;S61982:22

6. Loto RT, Loto CA, Popoola AP, Ranyaoa M. Corrosion resistance of austenitic stainless steel in sulphuric acid. Int $J$ Phys Sci 2012;7:1677-88.

7. Lin MC, Lin SC, Lee TH, Huang HH. Surface analysis and corrosion resistance of different stainless steel orthodontic brackets in artificial saliva. Angle Orthod 2006;76:322-9.

8. Kao CT, Ding SJ, Min Y, Hsu TC, Chou MY, Huang TH. The cytotoxicity of orthodontic metal bracket immersion media. Eur J Orthod 2007;29:198-203.

9. Sauza RM, Menezes LM. Nickel, chromium and iron levels in the saliva of patientswith simulated fixed orthodontic appliances. Angle Orthod 2008;78:345 